\title{
Riesgo sistémico fundamental que el adulto mayor enfrenta ante el COVID 19 en México, Brasil y EUA
}

\author{
Marcos David Silva Castañeda'
}

En cualquier pandemia, el propósito epidemiológico primordial es evitar que la enfermedad se propague. Este objetivo es alcanzable solo si se ubican, aíslan y tratan los contagios importados. Esto sin considerar cierres fronterizos, uso obligatorio de cubrebocas, inmediatos confinamientos, así como masivas pruebas diagnósticas. "Test, test, test" repetía en marzo de 2020 con lágrimas en los ojos el Dr. Tedros Adhanom Director General de la Organización Mundial de la Salud (OMS).

Los Estados tienen facultades exclusivas para lograr cada uno de estos objetivos estratégicos. Los particulares no disponen de los órganos estatales. Tampoco encabezan el sistema nacional de salud pública ni decretan confinamientos u obligatoriedad del cubrebocas. Igualmente, no cuentan con los recursos humanos, materiales, económicos y epidemiológicos que sí tienen a su alcance los gobiernos.

Cada uno de los decesos o contagios por COVID 19, en México o Brasil, tienen conexión, conforme rastreamos la cadena de propagación, con un contagio importado, solo si éstos se detectan oportunamente se evita la transmisión de la enfermedad no antes, no de otra forma.

La Primera Ministra de Nueva Zelanda, Jacinda Ardern, resumió su estrategia de la siguiente forma: "eliminar (evitar) la curva (de contagios importados) no aplanarla". Según el Instituto Lowy, por su manejo epidemiológico, Nueva Zelanda alcanzó la nota más alta entre 100 países evaluados, más de 90 puntos de 100 posibles. México, por el contrario, obtuvo 6 puntos.

Los gobiernos que detectaron asilaron y atendieron inmediatamente los casos importados impidieron la propagación del virus. Australia, por ejemplo, a finales de enero de 2021, no registró contagios ni decesos por COVID 19 , actualmente su vida social se desarrolla normalmente.

Podemos mencionar a Vietnam que hasta finales de 2020 no reportó decesos por COVID 19. Otros ejemplos son Taiwán, Tailandia, Uruguay o China, epicentro de la pandemia, con una población de más de mil millones de habitantes, actualmente registra un total de 4, 635 decesos.

La lección es evidente: detectar, asilar y tratar los casos importados es esencial para enfrentar una pandemia. Muchos países, como México o EUA, pudieron preparase con antelación. Sin embargo, a través de sus respectivos gobiernos, desconocieron, desde un inicio, cualquier interés por los casos importados: ¿las consecuencias? Altas tasas de mortalidad, positividad y letalidad por COVID 19 en México, Brasil y EUA. Según el INSP más del 60 $\%$ del total de decesos por COVID 19 en México tiene al menos 60 años. El COVID 19 ha golpeado gravemente, epidemiológicamente hablando, a este grupo poblacional. Seis de cada diez decesos por COVID 19 es un adulto mayor.

En los inicios de la epidemia de EUA, el Presidente Trump declaró que: "esto (SIC, refiriéndose al virus de la Covid-19) afecta virtualmente a nadie, es maravilloso". En otro momento, sin ningún tipo de evidencia, afirmó: "El riesgo para el pueblo estadounidense sigue siendo muy bajo". Por su parte, el Presidente brasileño Jair Bolsonaro, en la primera mitad del año pasado, afirmó: "no hay motivos de pánico", "se está sobredimensionando el poder destructivo de este virus", "es una fantasía lo del coronavirus". Cada uno de los Jefes de Gobierno de estos países negaron públicamente, en diferentes momentos, la

\footnotetext{
${ }^{1}$ Escuela Nacional de Trabajo Social de la UNAM. Av. Universidad 3000, C.U., Coyoacán, 04350 Ciudad de México, CDMX, México. Correspondence to: MDS Castañeda. E-mail: <ikebana.marcos.david@gmail.com>.
}

Como citar este artigo / How to cite this article

Castañeda MDS. Riesgo sistémico fundamental que el adulto mayor enfrenta ante el COVID 19 en México, Brasil y EUA. InterAm J Med Health 2021;4:e202101011. https://doi. org/10.31005/iajmh.v4i.190 
gravedad del COVID 19, llegando incluso a cuestionar la objetividad de los llamados a la acción gubernamental de la OMS. Al mismo tiempo, nunca usaron ni promovieron el cubrebocas.

Los gobiernos de Brasil, México y EUA no se abocaron a encontrar los contagios importados, como mencionábamos, pero tampoco concentraron sus esfuerzos gubernamentales en aislarlos ni ponerlos en tratamiento, mucho menos rastrearon sus contactos, efectivamente, a través de pruebas, pruebas, pruebas y más pruebas. Fueron omisos en cierres fronterizos expeditos, uso generalizado de cubrebocas, cuarentenas obligatorias en vuelos internacionales, así como confinamientos ipso facto. Sus gobernantes fueron escépticos ante los llamados de alarma de la OMS, minimizando incluso la importancia del cubrebocas. En el caso mexicano, optó catalogar, sin ninguna evidencia, que la mortalidad del COVID 19 era menor que el de la influenza. Sin base epidemiológico alguna, el Jefe del Estado mexicano, declara en Palacio Nacional, el 28 de febrero de 2020, que el COVID 19 "ni siquiera es equivalente a la influenza". Agregó que no se "debería ver como algo terrible o fatal" "no pasa nada con eso del coronavirus" (SIC) declaró tajante el 4 de marzo de 2020.

El subsecretario de Prevención y Promoción de la Salud, Hugo López-Gatell Ramírez haciendo caso omiso de las advertencias de la OMS, justificó "los datos indican que se trata de una enfermedad de baja virulencia comparada incluso con la influenza". Desafortunadamente, el virus COVID 19 sí fue fatal, sí fue algo terrible, y no, no fue menos peligroso que un catarro, y sí, como advirtió el Dr. Tedros, desde marzo del año pasado, más virulento, más contagioso y letal que la influenza. En síntesis, los tres gobiernos eligieron la inacción ante el COVID 19, según la OMS este 5 de febrero del 21:

1) 2.29 millones de decesos por Covid 19 en el planeta, transitamos de 118, mil contagios (en marzo del año pasado) a 105 millones en febrero de 2021.

2) México es uno de los países que, a lo largo de toda la pandemia, menor número de pruebas ha realizado por cada 100 mil habitantes, sin pruebas es imposible tener el control una pandemia. Nuestro país instaló hasta enero del 2021 un puesto de pruebas COVID 19 en el Aeropuerto de la Ciudad de México.

3) México ya tiene la más alta mortalidad por COVID 19 en América Latina en enero 21 por encima de Brasil y Perú, alcanzando un alarmante 59.2 fallecidos por COVID 19 por millón de habitantes. México, Brasil y EUA son los tres países del continente con más decesos y contagios por COVID 19.

4) 11.8 millones de nuevos pobres tan solo hasta octubre de 2020 según el CONEVAL, 6.8 millones de ellos en pobreza extrema. Más de 1 millón de PYMES han cerrado. Cadenas de cine y aerolíneas están al punto del cierre definitivo. Mientras China o Australia, no se diga Uruguay, registran tasas positivas de crecimiento económico. Hacer pruebas, para detectar casos importados, salva vidas y protege las economías.

5) El 5 de febrero de 2021 EUA colocó 1 millón 800 mil vacunas en un solo día, en la misma fecha el Gobierno no más de 3 mil vacunas. Dato alarmante, si consideramos que en los dos últimos meses el Gobierno mexicano no ha podido colocar las cerca de 800 mil en un mes y medio, EUA coloca el doble, por día.

Un riesgo sistémico es aquel del cual no tenemos ningún control, afecta a todas las personas sin distinción. El principal riesgo sistémico de los adultos mayores en México, Brasil y EUA, durante la pandemia por COVID 19, han sido sus propios gobiernos. A lo largo de la pandemia aquellos se han convertido en la principal amenaza a la vida de sus gobernados. Especialmente de los adultos mayores.

El gobierno de EUA ha reculado con el arribo del Presidente Joe Biden, no existen visos de un cambio sanitario equivalente en México o Brasil en el mediano o largo plazo. Los adultos mayores, como el resto de la población, no tienen ningún tipo de injerencia sobre las decisiones epidemiológicas de sus gobiernos. Empero, como personas, en algunos casos, tienen control de ciertos riesgos no sistémicos. O sea, aquellos peligros de los cuales tienen algún tipo de influencia. Para efectos prácticos, debemos decir que la pandemia por COVID 19 en México está fuera de control. El virus se ha esparcido por toda la República mexicana. Ante un escenario tan preocupante como funesto, vaya trabalenguas, lo único que tienen a su alcance los adultos mayores (y el resto de la sociedad mexicana) es buscar controlar el mayor número de riesgos no sistémicos para protegerse lo mejor posible del riesgo sistémico más grave de todos (incluso, considerando el propio virus): la conducción gubernamental del Estado mexicano de la pandemia por COVID 19. 